(c) 2008 Elsevier Ltd All rights reserved.

\title{
First report on azaspiracid and yessotoxin groups detection in French
} shellfish

\author{
Zouher Amzil ${ }^{\mathrm{a},{ }^{*}}$, Manoella Sibat ${ }^{\mathrm{a}},{\text { Florence } \text { Royer }^{\mathrm{a}} \text { and Véronique Savar }}^{\mathrm{a}}$ \\ a IFREMER, Microbiology and Phycotoxins Department, BP 21105, 44311 Nantes, France \\ *: Corresponding author : Z. Amzil, email address : Zouher.Amzil@ifremer.fr
}

\begin{abstract}
:
The French Phytoplankton and Phycotoxins monitoring network (REPHY) recently found positive or dubious negative shellfish samples using lipophilic toxins mouse bioassay. These samples were analyzed by liquid chromatography (LC) in combination with mass spectrometry (MS) to detect the following toxins: okadaic acid (OA), dinophysistoxins (DTXs), pectenotoxins (PTXs), azaspiracids (AZAs), yessotoxins (YTXs), spirolides (SPXs) and gymnodimines (GYMs). Over the 2006-2007 period, chemical analyses revealed various lipophilic toxin profiles according to shellfish sampling locations. In addition to OA and/or PTX-2 and their derivatives, several other compounds were found for the first time in France: (1) during the summer of 2006, AZA-1 and AZA-2 in Queen scallops (Aequipecten opercularis) from Northern Brittany; (2) during the summer of 2007, YTX and its major metabolites (45-hydroxy-YTX, homo-YTX, carboxy-YTX) in shellfish from the Mediterranean coast. Regarding YTX-group, the toxin profiles evolution in mussels during summer showed that: (i) the carboxy-YTX depuration rate was much slower than the YTX and 45-hydroxy-YTX ones; (ii) the homoYTX concentration, which was initially very weak, increased significantly during the last depuration phase, which seems to reveal a YTX-group high metabolisation level in mussels. This paper reports for the first time on AZA and YTX-groups detection in French shellfish.
\end{abstract}

Keywords: Lipophilic toxins; Azaspiracid group; Yessotoxin group; Shellfish; LC-MS/MS analyses 


\section{Introduction}

Yessotoxin (YTX) and azaspiracid (AZA) groups belong to the lipophilic phycotoxins family which also includes okadaic acid "OA", pectenotoxins "PTX", spirolide "SPX" and gymnodimine "GYM" groups. The European Commission (EC, 2002) set sanitary thresholds at $160 \mu \mathrm{g}$ OA-equivalent $/ \mathrm{kg}$ of whole tissue for both OA and PTX groups, $160 \mu \mathrm{g}$ AZA-1-eq/kg of whole tissue for AZA group and $1 \mathrm{mg}$ YTX-eq/kg of whole tissue for YTX group.

Yessotoxins are sulphated polyethers; they were isolated for the first time in the Japanese scallop Patinopecten yessoensis (Murata et al., 1987; Suzuki et al., 2007) and were also detected in mussels in Norway (Lee et al., 1989; Aasen et al., 2005). YTX occurrence in shellfish was observed later on in New Zealand and in Chile (Yasumoto and Takizawa, 1997; MacKenzie et al., 2002), in Italy (Satake et al., 1997; Ciminiello et al., 1997), in Spain (Arevalo et al., 2004), in the UK and in Canada (Stobo et al., 2003). In addition to YTX, but to a lesser extent, several analogues (fig. 1) have been identified in both shellfish and potentially causative dinoflagellates: Protoceratium reticulatum (= Gonyaulax grindleyi) (Satake et al., 1999; Ciminiello et al., 1998; 2000; 2003; Aasen et al., 2005; Miles et al., 2005; Paz et al., 2007; Suzuki et al., 2007); Lingulodinium polyedra (= Gonyaulax polyedra) (Tubaro et al., 1998; Paz et al., 2004; Draisci et al., 1999) and Gonyaulax spinifera (Rhodes et al., 2006). According to Tubaro et al. (1998; 2003), YTXs do not cause diarrhoea in mice when administered via intra-peritoneal or oral routes.

Azaspiracids (AZAs), polyethers having a carboxylic acid function and a cyclic imine function, were the latest diarrheic toxins from DSP toxins (Diarrheic Shellfish Poisoning) to be identified. They were detected for the first time in 1995 in Killary Bay, Ireland, following some diarrheic-type human poisoning at least eight people affected after eating mussels (Satake et al., 1998). A dozen homologues have been since identified (Ofuji et al.,1999; 2001; Lehane et al., 2004). Among them, AZA-1, and to a lesser degree, AZA-2 and AZA-3 (fig. 2) are the main contributors to potential toxicity towards man, due to their high concentrations, together with a high toxicity (Ito et al., 1998; 2000). A recent toxicological study of several synthetic AZA analogues, including AZA-1, has shown a strong biological activity linked to the basic molecular conformation of AZA-1. This activity induced changes in target organs (digestive tract, liver, thymus and spleen) as well as in observed pathologies (Ito et al., 2006). AZA group was reported later on in other countries than Ireland. They were detected in mussels in England and in Norway (James et al., 2002; Aasen et al., 2006); in oysters, clams and cockles in Ireland (Furey et al., 2003) and recently in brown crabs collected on the Swedish West coast and the Norvegian North-West coast (Torgesen et al., 2008).

AZA-1, AZA-2 and AZA-3 have been identified in a heterotrophic dinoflagellate Protoperidinium crassipes. Yet, these toxins source has not been confirmed so far, since AZAs accumulated in $P$. crassipes might originate from another phytoplanktonic prey ingested (Yasumoto 2001a; James et al., 2003).

Concerning lipophilic toxins in France, as soon as Dinophysis spp. occurrence is reported, the phytoplankton \& phycotoxins monitoring network (REPHY) performs toxicity analyses, on a weekly basis throughout the risk period, on exposed bivalves, using mouse bioassays designed for lipophilic toxins. For positive mouse-bioassay shellfish samples, liquid chromatography in combination with mass spectrometry (LC-MS/MS) is used to search for the following lipophilic toxins: OA, PTX, AZA, YTX, SPX and GYM groups. Until 2004, shellfish from French farming areas were regularly contaminated by OA and PTX-2 groups associated with the presence of Dinophysis spp. species (Masselin et al., 1992; Lassus et al., 1988; Mondeguer et al., 2006; Amzil and Mathias, 2006; Amzil et al., 2007). Spirolides (SPX-A, SPX-desMeC) were discovered in 2005 on the Atlantic coast (Bay of Arcachon) in association with Alexandrium ostenfeldii (Amzil et al., 2007).

In addition to these toxins, other lipophilic toxins detected for the first time in France include: i) AZAgroup during the summer of 2006 in Queen scallops (Aequipecten opercularis) originating from shellfish beds off Northern Brittany; ii) YTX-group during the summer of 2007, in shellfish originating from the Mediterranean coast. As these two families of toxins have never been detected so far in French shellfish production areas, this report deals with the first recorded occurrence of AZA and YTX groups in French shellfish. 


\section{Materials and methods}

Reference materials

- Lipophilic toxin standard solutions for OA, YTX, PTX-2, SPX-desMeC and GYM were provided by NRC-Halifax, Canada. Certified AZA reference materials were generously donated by Dr. Mike Quilliam in 2006 (NRC-Canada) before their commercialisation in 2007.

- Italian mussel samples containing YTX-group:YTX, homo-YTX, 45-YTX, 45-homo-YTX.

\section{Shellfish samples}

Shellfish samples were collected at different production sites along the French coastline that had experienced closures due to lipophilic toxins presence. Shellfish samples were mussels, oysters, clams from Mediterranean coast and Queen scallops from Northern Brittany. For shellfish samples, with the exception of scallops, at least $30 \mathrm{~g}$ hepatopancreas (HP) was homogenized in a blender. Twenty grams $(20 \mathrm{~g})$ were used for the lipophilic toxins mouse bioassay following a method adapted from Yasumoto et al. (1984). For Queen scallops, a minimum of $110 \mathrm{~g}$ of whole tissue was homogenized in a blender. $100 \mathrm{~g}$ were used for the mouse bioassay according to Hannah et al. (1995). The bioassay was considered positive if at least two out of three mice died within 24 hours. The remaining HP and whole tissue $10 \mathrm{~g}$ homogenate were used later on for LC-MS/MS analyses.

\section{Extraction procedure for lipophilic toxins}

Figure 3 shows the complete extraction procedure: lipophilic toxins were extracted from $2 \mathrm{~g}$ HP or whole tissue homogenate as indicated by the DSP mouse-assay extraction protocol. The resulting $\mathrm{CH}_{2} \mathrm{Cl}_{2}$ phase was then dried and diluted in $\mathrm{MeOH}$. One aliquot was used for lipophilic toxin analyses (with the exception of "DTX-3" acyl-esters), and a second aliquot for DTX-3 alkaline hydrolysis to release OA and/or DTX-1 and/or DTX-2, and subsequent analyses of DTX3. For toxins quantification, a calculated HP/whole tissue ratio was used to express all the results to the whole tissue from the amount found in HP.

\section{LC/MS-MS analyses of lipophilic toxins}

For each shellfish sample, LC-MS/MS analyses were performed on two aliquots (before and after hydrolysis) in our investigation of lipophilic toxins (figure 3).

$5 \mu \mathrm{l}$ of each aliquot was injected into the LC-MS/MS system using an Agilent 1200 LC model coupled to a hybrid triple quadrupole/linear ion trap mass spectrometer (API-4000-Q-Trap, PE/SCIEX) equipped with a Turbo $V$ ion spray ${ }^{\circledR}$ source. LC-MS/MS analyses were performed by modifying the Quilliam method (Quilliam et al., 2001). Toxins were separated in a $3 \mu \mathrm{m}$ MOS-Hyperclone C8 column $\left(50 \mathrm{~mm} \times 2 \mathrm{~mm}\right.$ id, Phenomenex) at $20^{\circ} \mathrm{C}$. The mobile phase was $100 \%$ water containing $2 \mathrm{mM}$ ammonium formate and $50 \mathrm{mM}$ formic acid (channel A) and acetonitrile/water (95/5) containing $2 \mathrm{mM}$ ammonium formate and $50 \mathrm{mM}$ formic acid (channel B). Two different linear gradients were used. Gradient elution 1 for multi-toxin determination started with 30-95\% B for $2.5 \mathrm{~min}$, followed by an 8 min hold at $95 \%$ B and $5 \%$ A, and decreasing to $30 \%$ B over $0.5 \mathrm{~min}$, which was held again for 5 min until the next run. Gradient elution 2 was used for the YTX-group determination, starting with $5-100 \%$ B for $6 \mathrm{~min}$, followed by a $6 \mathrm{~min}$ hold at 100\% B, and decreasing to 5\% B over $1 \mathrm{~min}$, which was held again for 7 minutes until the next run. The mobile phase flow-rate was set at $200 \mu \mathrm{l} \mathrm{min}{ }^{-1}$. Instrument control, data processing and analysis functions were all provided by Analyst software ${ }^{\circledR}$.

Analyses were carried out using two different methods for each toxin group: negative ion mode was used for YTX-group, while positive ion mode was used for the others groups of toxins (OA, PTX, AZA, SPX, GYM). The electrospray ionization interface (ESI) was set with the following parameters: curtain gas: 30 and 10 for YTX; temperature: $450^{\circ} \mathrm{C}$ and $600^{\circ} \mathrm{C}$ for YTX; gas 1: 50 and 40 for YTX; gas 2: 50; CAD gas: medium; Ion spray voltage: $5,500 \vee$ and $-4,500 \vee$ for YTX. These parameters had been previously optimized using toxin standards. The mass spectrometer was operated in multiple reactionmonitoring (MRM), analysing the two or three most intense product ions per compound. Italian mussel sample containing, in addition to YTX, homo-YTX, 45-YTX, 45-homo-YTX, was used in our investigation of these toxins. 
The LOD and LOQ for all toxin groups studied are expressed in $\mu \mathrm{g} / \mathrm{kg}$ of whole tissue: OA $(0.8$ and 3.5); PTX-2 (0.1 and 0.6); SPX-desMeC (0.2 and 0.8), GYM (0.02 and 0.07); AZA-1 (0.2 and 0.8); YTX (0.4 and 1.5).

\section{Results}

Detection of AZA group in French shellfish for the first time

In August 2006, as part of the systematic monitoring of Queen scallop breeding grounds during the fishing season, samples originating from Northern Brittany produced a doubtful result on mice according to the method of Hannah et al. (1995) for lipophilic toxins. Indeed, the mouse assays considered to be unreliable were those leading to the following results: i) one mouse death among three within 24 hours; ii) mice exhibiting diarrheic type symptoms without mortality; iii) mice mortality after the 24-hour period (positive between 24 and 72 hours). The AZA-group could, in fact, cause death in mice either in a relatively short time (20-60 $\mathrm{min}$ ) for strong doses, or in a period exceeding 24 hours (2 to 3 days) for lower doses (FAO/IOC/WHO, 2004).

Chemical analyses conducted on homogenized portions of whole tissue taken from these samples revealed the presence of AZA -1 and AZA-2 in French shellfish production areas for the first time. Figure 4 shows an example of the analytical result obtained by LC-MS/MS on a Queen scallops sample originating from shellfish beds off the North Brittany coast. In addition to AZA-1,-2, OA and its acyl ester derivatives (DTX-3) were also detected in low concentrations (maximum of $16 \mu \mathrm{OA}$ eq/ $\mathrm{Kg}$ of whole tissue, not shown here). Figure 5 gives the proportions of AZA-1 and AZA-2 in the whole tissue of the Queen scallops during the August-December 2006 contamination period. The maximum concentration of AZA-group was close to $274 \mu \mathrm{g}$ AZA-1 eq/kg of whole tissue, which was in excess of the sanitary threshold (160 $\mu \mathrm{g} \mathrm{AZA-1} \mathrm{eq/kg} \mathrm{of} \mathrm{whole} \mathrm{tissue).} \mathrm{We} \mathrm{can} \mathrm{note} \mathrm{that} \mathrm{for} \mathrm{all} \mathrm{samples} \mathrm{AZA-1}$ was the main toxin encountered compared with AZA-2: on average $80 \%$ and $20 \%$ respectively. According to Figure 5, showing samples toxin profiles, the AZA-group content changes over time in two distinct stages: a contamination phase starting around the middle of August at a low concentration (7 $\mu \mathrm{g} \mathrm{AZA-1} \mathrm{eq/Kg}$ of whole tissue) followed by a sharp increase and a toxicity peak $(274 \mu \mathrm{g} / \mathrm{kg}$ of whole tissue), and then a slow depuration phase until the end of December (4 $\mu \mathrm{g} A Z A-1 \mathrm{eq} / \mathrm{kg}$ of whole tissue).

AZA-group distribution study in Queen scallops different organs (digestive glands, muscle, remaining tissue) revealed them to be concentrated mainly in the digestive glands (approximately 95\%), with a small quantity being found in the remaining tissue (about 5\%), and with no trace at all in the muscle.

\section{Detection of YTX group in French shellfish for the first time}

During the June-September 2007 period, mice injected with shellfish extracts (mussels, oysters and clams) originating from the Mediterranean coast, following the procedure for the official DSP test, exhibited neurological symptoms (convulsion and jump) causing death at the end of a very short survival time of between 10 and 40 minutes. Chemical CL-SM/SM analyses conducted on the same shellfish homogenates revealed the presence of YTX and its metabolites for the first time in France. The maximum concentration of YTX equivalent found in mussels (approximately $100 \mu \mathrm{gTX}$ eq/Kg of whole tissue) was 10 times less than the sanitary threshold (1,000 $\mu \mathrm{g} Y \mathrm{YX} \mathrm{eq} / \mathrm{kg}$ of whole tissue). In contrast to mussels, the YTX-group was found in trace amounts in oysters and clams (maximum of 2 $\mu \mathrm{g} \mathrm{YTX} \mathrm{eq/Kg} \mathrm{of} \mathrm{whole} \mathrm{tissue).} \mathrm{Figure} 6$ shows a mussel sample toxin profile collected in July 2007: YTX, 45-hydroxy-YTX, homo-YTX, 45-homo-YTX, carboxy-YTX, carboxy-homo-YTX and ATX (Adriatoxin).

YTX and its main metabolites concentration (45-hydroxy-YTX, homo-YTX, carboxy-YTX) as well as ATX one were monitored in mussel samples collected between June and September 2007 inside the Ingril lagoon (Mediterranean coast) (fig. 7). The contamination peaked around mid-June and was followed by a progressive depuration phase during July, and then a long purification phase during August to September. 


\section{Discussion and conclusion}

AZA-1 predominance in shellfish in conjunction with AZA-group accumulation in mussels has already been reported in various different geographic areas (Norway, UK, Ireland) (James et al., 2001; 2002). As shown in French Queen scallops contamination, the AZA-group remains for about 4 months. The way AZA-group persists over time in shellfish has already been observed and reported during a toxic episode that occurred in Ireland, where the contamination period lasted approximately 8 months (James et al., 2001). The non-accumulation of AZA-group in Queen scallops muscle from shellfish beds off Northern Brittany has been observed in the past in relation to other toxins (okadaic acid, domoic acid) during DSP and ASP (Amnesic Shellfish Poisoning) toxic episodes that affected scallop shellfish beds off Northern Brittany and in the English Channel during the period from the end of 2004 to the end of 2005 (Amzil et al, in press). In comparison with other shellfish species (mussels), research conducted by James et al. (2002) has shown that the majority of AZA-group was found in the digestive glands (around 93\%) and only a minority in the rest of the flesh (around 7\%). While Hess et al. (2005) showed that AZAs behave like the other lipophilic toxins, accumulating mainly in the digestive glands.

As the distance from the coast of the Queen scallop beds in Northern Brittany, and their depth, did not allow us to collect significant plankton samples, we do not possess the data necessary to identify the causative agent. At an international level, following the first appearances of AZA-group in Ireland, these toxins were identified in a heterotrophic dinoflagellate Protoperidinium spp. (Yasumoto 2001a; James et al., 2003). Meanwhile, the origin of these toxins has yet to be confirmed, since few questions remain unanswered in relation to $P$. crassipes: i) Is it a AZAs producer? ii) does it accumulate AZAs by preying upon another species? iii) does it ingest a precursor of AZA from the prey species that is then metabolized subsequently into AZA-1, -2 or -3 ?

As regards the accumulation of YTX group in French shellfish originating from the Mediterranean, toxin profiles evolution shows that the YTX group remains in the shellfish during four months and this agrees with bibliographical data (Ramstad et al., 2001; Mackenzie et al., 2002; Aasen et al., 2005; Samdal et al., 2005). According to Mackenzie et al. (2001), the YTX half-life is estimated at 49 days in New Zealand mussels (Greenshell ${ }^{\mathrm{TM}}$ mussels) while it is only 20 days in Norwegian mussels (Mytilus edulis) (Aasen et al., 2005). This difference is probably due to the different ways YTX is metabolised by these two mussel species, which depend on seasons, bivalves physiological condition, phytoplankton species present, and water temperature. Metabolism can indeed be seen to play an important role when we compare YTX and its principal metabolites proportions in different shellfish species. In New Zealand Greenshell ${ }^{\mathrm{TM}}$ mussels (Perna canaliculus), YTX is predominant (Mackenzie et al., 2001) while in Norwegian blue mussels (Mytilus edulis), concentrations of YTX, 45-hydroxyYTX and carboxy-YTX are equivalent (Aasen et al., 2005). For the French Mediterranean species of mussels (Mytilus galloprovincialis), it is YTX that predominates. According to Figure 7, depuration rate for carboxy-YTX is much slower than that of YTX and 45-hydroxy-YTX, since the low concentration of carboxy-YTX does not change significantly over time. Aasen et al. (2005) have observed equivalent depuration patterns in Norwegian mussels with a carboxy-YTX half-life that is three times longer than that of YTX (60 days). As regards French mussels, the evolution of their toxin profiles evolution (fig. 7) shows that homo-YTX concentration very low to start with, increases significantly during the final depuration phase, and this suggests that a transformation of some kind had occurred in the mussels. Phytoplanktonic examinations of samples collected at the end of August enabled identification of two species, potentially YTXs producers, and present in low concentrations: Lingulodinium polyedrum (= Gonyaulax polyedra) and Gonyaulax spinifera. YTX-group accumulation in shellfish in the presence of low concentrations of producer phytoplankton has already been observed in Norway (Aasen et al., 2005). These Authors indicated that a low density Protoceratium reticulatum occurrence, during a short period, is sufficient to cause YTX-group accumulation in mussels at levels higher than the sanitary threshold.

The YTX group doesn't usually cause diarrhoea and their human toxicity has never been proved (Tubaro et al., 1998; 2003). The YTX toxic potential after per os administration seems to be low and its relevance is still not completely clarified (Aune et al., 2002; Tubaro et al., 2003). According to a report prepared following $\mathrm{FAO} / \mathrm{IOC} / \mathrm{WHO}$ experts consultations, the majority of any dose of YTX administered to mice via the oral tract is found in the faeces, indicating that insignificant absorption takes place in the gastro-intestinal tract (FAO/IOC/WHO, 2004). YTX-group do, however, present a cytotoxic potential in vitro (Alfonso et al., 2003; Perez-Gomez et al., 2006). There is no proof of YTXs being toxic to man, and, the $\mathrm{FAO} / \mathrm{IOC} / \mathrm{WHO}$ experts (2004) suggested changing the regulatory level 
from $1 \mathrm{mg} / \mathrm{kg}$ to $12 \mathrm{mg} / \mathrm{kg}$ of shellfish meat. Furthermore, the Codex Committee on Fish and Fishery Products (CCFFP) has suggested to de-regulate YTXs due to low oral toxicity.

During the period June-September 2007, in addition to the YTX group presents in concentrations considerably lower than the sanitary threshold, other lipophilic toxins families were also detected in samples collected at the start of the episode, in very low concentrations: OA group (max $40 \mu \mathrm{g} \mathrm{OA}$ eq/kg of whole tissue), PTX group (PTX-2/PTX-sa/PTX-2-sa epimer: max $70 \mu \mathrm{g}$ PTX-2 eq/kg of whole tissue) and traces of SPX-group (below $5 \mu \mathrm{g} \mathrm{SPX-desMeC} \mathrm{eq/kg} \mathrm{of} \mathrm{whole} \mathrm{tissue).} \mathrm{This} \mathrm{meant} \mathrm{it} \mathrm{was}$ difficult to assess the impact on public health of all the different toxin families, since no data were available on the possible additive, synergistic or antagonistic effects these different toxins might have on one another. On behalf Precautionary Principle, contaminated shellfish production sites were closed by Public Authority during this toxic episode, and with serious economic repercussions for Mediterranean shellfish producers.

We need to be mindful of the fact that mice treated in conformity with the biological testing procedures established by Yasumoto (Yasumoto et al., 1978; 1984) with extracts of shellfish containing concentrations lower than the sanitary threshold $(1,000 \mu \mathrm{g} Y T X ~ e q / \mathrm{kg}$ of whole tissue) can exhibit neurological symptoms followed quickly by death (Aune et al., 2002; Tubaro et al., 2003).

Yasumoto (2001b) proposed a two protocols analytical procedure for preparing extracts of shellfish whole tissue: 1) a first protocol for extracting the different toxin groups classified as diarrheic on the one hand, and demonstrating their presence using mouse-assay on the other; 2) a second protocol that can be applied if the first test suggests the YTX group is present, which evaluates neurological symptoms in mice. This protocol could be applied to the same batch of shellfish with the aim of separating the YTX-group from other toxin groups: i) a phase inlcuding the YTX group being the object of a 5-hour DSP mouse-assay (5-hour YTX mouse-assay) adapted to detect YTX-group and ii) an organic phase enclosing the other toxin groups (OA, PTX, AZA) which were revealed via the 24-hour DSP mouse-assay.

\section{Acknowledgements}

The authors would like to thank all participating staff from Ifremer coastal laboratories: Liliane Fiant, Claude Chiantella, Sylvaine Françoise and Eric Abadie for sample collection, and for providing us with essential information about the mouse tests results, and Elisabeth Nezan for morphological identification of phytoplankton. Pierre Masselin and Patrick Lassus for valuable help with English manuscript. We would also like to express our gratitude to Dr. Mike Quilliam and his staff at the NRCCanada for generously providing us with certified Azaspiracids reference material.

\section{References}

Aasen J., Samdal I.A., Miles C.O., Dahl E., Briggs L.R., Aune T., 2005. Yessotoxin in Norwegian blue mussels (Mytilus edulis): uptake from Protoceratium reticulatum, metabolism and depuration. Toxicon 45, 265-272.

Aasen J., Torgersen T., Dahl E., Naustvoll L.J., Aune T., 2006. Confirmation of azaspiracides in mussels in Norwegian costal areas, and full profile at one location. In: Proceedings of the Fifth International Conference on Molluscan Shellfish Safety, Galway, Irland. Henshilwood K., Deegan B., McMahon T., Cusak C., Keaveney S., Silke J.O., Cinneide M., Lyons D. and Hess P. (eds), pp. 162169.

Alfonso A., De la Rosa L. A., Vieytes M.R., Yasumoto T., Botana L.M., 2003. Yessotoxin, a novel phycotoxin, activates phosphodiesterase activity. Effect of yessotoxin on cAMP levels in human lymphocytes. Biochem. Pharmacol. 65, 193-208.

Amzil Z., Royer F., Sibat M., Fiant L., Gelin M., Le Gal D., Françoise S. First report on Amnesic and Diarrheic toxins detection in French scallops during 2004 - 2005 monitoring Surveys. In: Proceedings of the Sixth International Conference on Molluscan Shellfish Safety, New Zeland (in press).

Amzil Z., Sibat M., Royer F., Masson N., Abadie E., 2007. Report on the First Detection of Pectenotoxin-2, Spirolide-A and Their Derivatives in French Shellfish. Marine Drugs Journal 5, 168179.

Amzil Z., Mathias A., 2006. First report on detection of okadaic acid 7-O-acyl-ester derivatives (DTX-3) in French shellfish. In: Proceedings of the Fifth International Conference on Molluscan Shellfish 
Safety, Galway, Irland. Henshilwood K., Deegan B., McMahon T., Cusak C., Keaveney S., Silke J.O., Cinneide M., Lyons D. and Hess P. (eds); pp. 150-161.

Arévalo F., Pazos Y., Correa J., Salgado C., Morono A., Paz B., Franco J.M., 2004. First report of yessotoxin in mussels of Galician Rias during a bloom of Lingulodinium polyedra stein (Dodge). In: Henshilwood, K., Deegan B., McMahon T., Cusak C., Keaveney S., Silke J.O., Cinneide M., Lyons D., Hess P. (Eds.). Fifth International Conference on Molluscan Shellfish Safety. Galway, Ireland, pp. 184189.

Aune T., Sorby R., Yasumoto T., Ramstad H., Landsverk T., 2002. Comparaison of oral and intraperitoneal toxicity of yessotoxin towards mice. Toxicon 40, 77-82.

Ciminiello P., Fattorusso E., Forino M., Magno S., Poletti R., Satake M., Viviani R., Yasumoto T., 1997. Yessotoxin in mussels of the northern Adriatic sea. Toxicon 35 (2), 177-183.

Ciminiello P., Fattorusso E., Forino M., Magno S., Poletti R., 1998. Isolation of adriatoxin a new analogue of yessotoxin from mussels of Adriatic Sea. Tetrahedron Lett., 39, 8897-8900.

Ciminiello P., Fattorusso E., Forino M., Poletti R., Satake M., Viviani R., 2000. A new analogue of yessotoxin, carboxy yessotoxin, isolated from Adriatic Sea mussels. Eur. J. Org. Chem., 291-295.

Ciminiello P., Dell'Aversano C., Fattorusso E., Forino M., Magno S., Guerrini F., Pistocchi R., Boni L., 2003. Complex yessotoxins profile in Protoceratium reticulatum from north-western Adriatic sea revealed by LC-MS analysis. Toxicon 42, 7-14.

Draisci R., Ferretti E., Palleschi L., Marchiafava C., Poletti R., Milandri A., Ceredi A., Pompei M., 1999. High levels of yessotoxin in mussels and presence of yessotoxin and homo-yessotoxin in dinoflagellates of the Adriatic Sea. Toxicon 37, 1187-1193.

European Commission decision 2002/225/EC (2002). Off. J. Eur. Commun., L75, 62-64.

$\mathrm{FAO} / \mathrm{IOC} / \mathrm{WHO}$. In: report of the joint $\mathrm{FAO} / \mathrm{IOC} / \mathrm{WHO}$ and ad hoc expert consultation on biotoxins in bivalve molluscs. Oslo, Norway, Sep. 26-30, 2004.

Furey A., Moroney C., Brana Magdalena A., Saez M.J.F., Lehane M., James K.J., 2003. Geographical, temporal, and species variations of the polyether toxins, azaspiracids, in shellfish. Environ. Sci. Technol. 37, 3078-3084.

Hess P., Nguyen L., Aasen J., Keogh M., Kilcoyne J., McCarron P., Aune T., 2005. Tissue distribution, effects of cooking and parameters affecting the extraction of azaspiracids from mussels, Mytilus edulis, prior to analysis by liquid chromatography coupled to mass spectrometry. Toxicon, 46, 62-71

Hannah D.J., Desmond G.T., Deverall T., Jones P.D., Fry J., 1995. Extraction of lipid-soluble marine biotoxins. J. AOAC int. 78 (2), 480-483.

Ito E., Terao K., McMahon T., Silke J., Yasumoto T., 1998. Acute pathological changes in mice caused by crude extracts of novel toxins isolated from Irish mussels. In : Harmful Algae. Reguera B., Blanco J., Fernandez M.L., Wyatt T. (Eds.). IOC of UNESCO and Xunta de Galicia, santiago de compostela, Spain, pp. 588-589.

Ito E., Satake M., Ofuji K., Kurita N., McMahon T., James K.J., Yasumoto T., 2000. Multiple organ damage caused by new toxin azaspiracid, isolated from mussels produced in Ireland. Toxicon 38, 917930.

Ito E., Frederick M.O., Koftis T.V., Tang W., Petrovic G., Ling T., Nicolaou K.C., 2006. Structure toxicity relationships of synthetic azaspiracid-1 and analogues in mice. Harmful Algae 5, 586-591.

James K.J., Furey A., Satake M., Yasumoto T., 2001. Azaspiracid poisoning (AZP). A new shellfish toxic syndrome in Europe. In: Harmful Algal Blooms 2000. Hallegraeff G.M., Blackburn S.I., Bolch C.J. and Lewis R.J. (eds). Intergovernmental Oceanographic Commission of UNESCO, pp. 250-253.

James K.J., Furey A., Lehane M., Ramstad H., Aune T., Hovgaard P., Morris S., Higman W., Satake M., Yasumoto T., 2002. First evidence of an extensive northern European distribution of azaspiracid poisoning (AZP) toxins in shellfish. Toxicon, 40, 909-915.

James K., Moroney C., Roden C., Satake M., Yasumoto T., Lehane M., Furey A., 2003. Ubiquitous 'benign' alga emerges as the cause of shellfish contamination responsible for the human toxic syndrome, azaspiracid poisoning. Toxicon 41, 145-151.

Lassus, P., Bardouil, M., Berthome, J.P., Maggi, P., Truquet, P., Le Dean, L., 1988. Seasonal occurrence of Dinophysis sp. along the French coast between 1983 and 1987. Aquat. Living Ressour., 155-164.

Lee J.S., Igarashi T., Fraga S, Dahl E., Hovgaard P., Yasumoto T., 1989. Determination of diarrhoeic shellfish toxins in various dinoflagellate species. Journal of Applied Phycology, 1, 147-152.

Lehane M., Saez M.J.F., Magdalena A.B., Canas I.R., Sierra M.D., Haamilton B., Furey A., James K.J., 2004. Liquid chromatography-multiple tandem mass spectrometry for the determination of ten azaspiracids, incluing hydroxyl analogues in shellfish. Journal of Chromatography A, 1024, 63-70.

MacKenzie A.L., Suzuki T., Adamson J., 2001. Elimination and differential transformation of yessotoxin by Greenshell mussel Perna canaliculus and the blue mussel Mytillus galloprovincialis. In: 
Hallegraeff G.M., Blackburn S.I., Bolch C.J., Lewis R.J. (Eds.), Harmful Algal Blooms, Hobart, Australia 2000. IOC of UNESCO, pp. 371-374.

MacKenzie A.L., Holland P., McNabb P., Beuzenberg V., Selwood A., Suzuki T., 2002. Complex toxin profiles in phytoplankton and Greenshell mussels (Perna canaliculus), revealed by LC-MS analysis. Toxicon 40, 1321-1330.

Masselin, P., Lassus, P., Bardouil, M., 1992. High performance liquid chromatography analysis of diarrhoeic toxins in Dinophysis spp. from the French coast. Journal of Applied Phycol., 4, 385-389.

Miles C.O., Samdal I.A., Aasen J.A.G., Jensen D.J., Quilliam M.A., Petersen D., Briggs L.M., Wilkins A.L., Rise F., Cooney J.M., MacKenzie L., 2005. Evidence for numerous analogs of yessotoxin in Protoceratium reticulatum. Harmful Algae 4, 1075-1091.

Mondeguer F., Genin E., Mestre G., Nsengiyumva C., 2006. Validation of an automated procedure of solid phase extraction of mussels digestive glands for identification and quantification of Dinophysistoxins in LC/ESI/MS2 by quadruple ion trap. In: Proceedings of the Fifth International Conference on Molluscan Shellfish Safety, Galway, Irland.. Henshilwood K., Deegan B., McMahon T., Cusak C., Keaveney S., Silke J.,O., Cinneide M., Lyons D. and Hess P. (eds), pp. 94-99.

Murata M., Kumagai M., Lee J.S., Yasumoto T., 1987. Isolation and structure of yessotoxin, a polyether compound implicated in diarrhetic shellfish poisoning. Tetrahedron Lett., 28, 5869-5872.

Ofuji K., Satake M., McMahon T., James K.J., Naoki H., Oshima Y., Yasumoto T., 1999. Two analogs of azaspiracids isolated from mussels, Mytilus edulis, involved in human intoxication in Ireland. Natural Toxins, 7, 99 - 102.

Ofuji K., Satake M., McMahon T., James K.J., Naoki H., Oshima Y., Yasumoto T., 2001. Structures of azaspiracid analogs, azaspiracid-4 and azaspiracid-5, causative toxins of azaspiracids poisoning in Europe. Biosci. Biotechnol. Biochem., 65, 740-742.

Paz B., Riobo P., Fernandez M.L., Fraga S., Franco J.M., 2004. Production and release of yessotoxins by the dinoflagellates Protoceratium reticulatum and Lingulodinium polyedrum in culture. Toxicon 44, 251-258.

Paz B., Riobo P., Ramilo I., Franco J.M., 2007. Yessotoxins profile of Protoceratium reticulatum from Spain and USA. Toxicon 50, 1-17.

Ramstad H., Hovgaard P., Yasumuto T., Larsen S., Aune T., 2001. Monthly variations in diarrhetic toxins and yessotoxin in shellfish from coast to the inner part of the Sognefjord, Norway. Toxicon 39, 1035-1043.

Pérez-Gomez A., Novelli A., Franco J.M., Paz B., Fernandez-Sanchez M.T., 2006. Potent neurotoxic action of the shellfish biotoxin yessotoxin on cultured cerebellar neurons. Toxicol. Sci. 90, 168-177.

Quilliam M.A, Hess P., Dell'Aversano C., 2001. Recent developments in the analysis of phycotoxins by liquid chromatography-mass spectrometry. In: Dekoe, W.J., Sampson, R.A., van Egmond, H.P., Gilbert J., Sabino, M. (Eds.). Mycotoxins and Phycotoxins in Perspective at the Turn of the Millenium. De Koe, W.J., Wageningen, The Netherlands, pp. 383-391.

Rhodes L., McNabb P., de Salas M., Briggs L., Beuzenberg V., Gladstone M., 2006. Yessotoxin production by Gonyaulax spinifera. Harmful Algae 5, 148-155.

Samdal I.A., Aesen J.A.G., Briggs L.R., Dahl E., Miles C.O., 2005. Comparison of ELISA and LC-MS analyses for yessotoxins in blue mussels (Mytilus edulis). Toxicon 46, 7-15.

Satake M., Mackenzie L., Yasumoto T., 1997. Identification of Protoceratium reticulatum as the biogenetic origin of yessotoxin. Natural Toxins, 5, 164-167.

Satake M., Ofuji K., Naoki H., James K.J., Furey A., McMahon T., Silke J., Yasumoto T., 1998. Azaspiracid, a new marine toxin having unique spiro ring assemblies, isolated from Irish mussels. $J$. Am. Chem. Soc., 120, 9967-9968.

Satake M., Ichimura T., Sekiguchi K., Yoshimatsu S., Oshima Y., 1999. Confirmation of yesotoxin and 45, 46, 47-trinoryessotoxin production by Protoceratium reticulatum collected in Japon. Natural Toxins 7, 147-150.

Stobo L.A., Lewis J., Quilliam M.A., Hardstaff W.R., Gallacher S., Webster L., Smith E., McKenzie M., 2003. Detection of yessotoxin in UK and Canadian isolates of phytoplancton and optimisation and validation of LC-MS methods. In: Eighth Canadian workshop on Harmful Marine Algae. Bates S. (Ed.). Gulf Fisheries Centre, Moncton, New Brunswick, Canada, pp. 8-14.

Suzuki T., Horie Y., Koike K., Satake M., Oshima Y., Iwataki M., Yoshimatsu S., 2007. Yessotoxin analogues in several strains of Protoceratium reticulatum in Japan determined by liquid chromatography-hybrided triple quadrupole/lineair ion trap mass spectrometry. Journal of Chromatography A, 1142, 172-177.

Torgersen T., Bremnes N.B., Rundberget T., Aune T., 2008. Structural confirmation and occurrence of azaspiracids in Scandinavian brown crabs (Cancer pagurus). Toxicon 51, 93-101. 
Tubaro A., Sidari L., Della Loggia R., Yasumoto T., 1998. Occurrence of yessotoxin-like toxins in phytoplankton and mussels from northern Adriatic sea. In: Harmful Algae. Reguera B., Blanco J., Fernandez M.L. \& Wyatt T. (eds). Xunta de Galicia and IOC of UNESCO, pp. 470-472.

Tubaro A., Sosa S., Carbonatto M., Altinier G., Vita F., Melato M., Satake M., Yasumoto T., 2003. Oral and intraperitoneal acute toxicity studies of yessotoxin and homoyessotoxins in mice. Toxicon 41, 783792.

Yasumoto T., Oshima Y., Yamaguchi M., 1978. Occurrence of a new type of shellfish poisoning in the Tohoku. District. Bull. Jpn. Soc. Sci. Fish., 44 (11), 1249-1255.

Yasumoto T., Murata M., Oshima Y., Matsumoto G.K., Clardy J., 1984. Diarrhetic Shellfish Poisoning. In: Sea Food Toxins, Ragelis E.P. (ed). ACS symposium series, ${ }^{\circ} 262$, pp. 208-214.

Yasumoto, T., Takizawa A., 1997. Fluorimetric measurement of yessotoxins in shellfish by highpressure liquid chromatography. Biosci. Biotechnol. Biochem. 61, 1775-1777.

Yasumoto T., 2001a. The chemistry and biological function of natural marine toxins. Chemical Record $1,228-242$.

Yasumoto T., 2001b. Suitability of two mouse assay methods to quantify marine toxins in bivalve molluscs. Submission to EU Reference Laboratory, Vigo, Spain. 13 pp. 


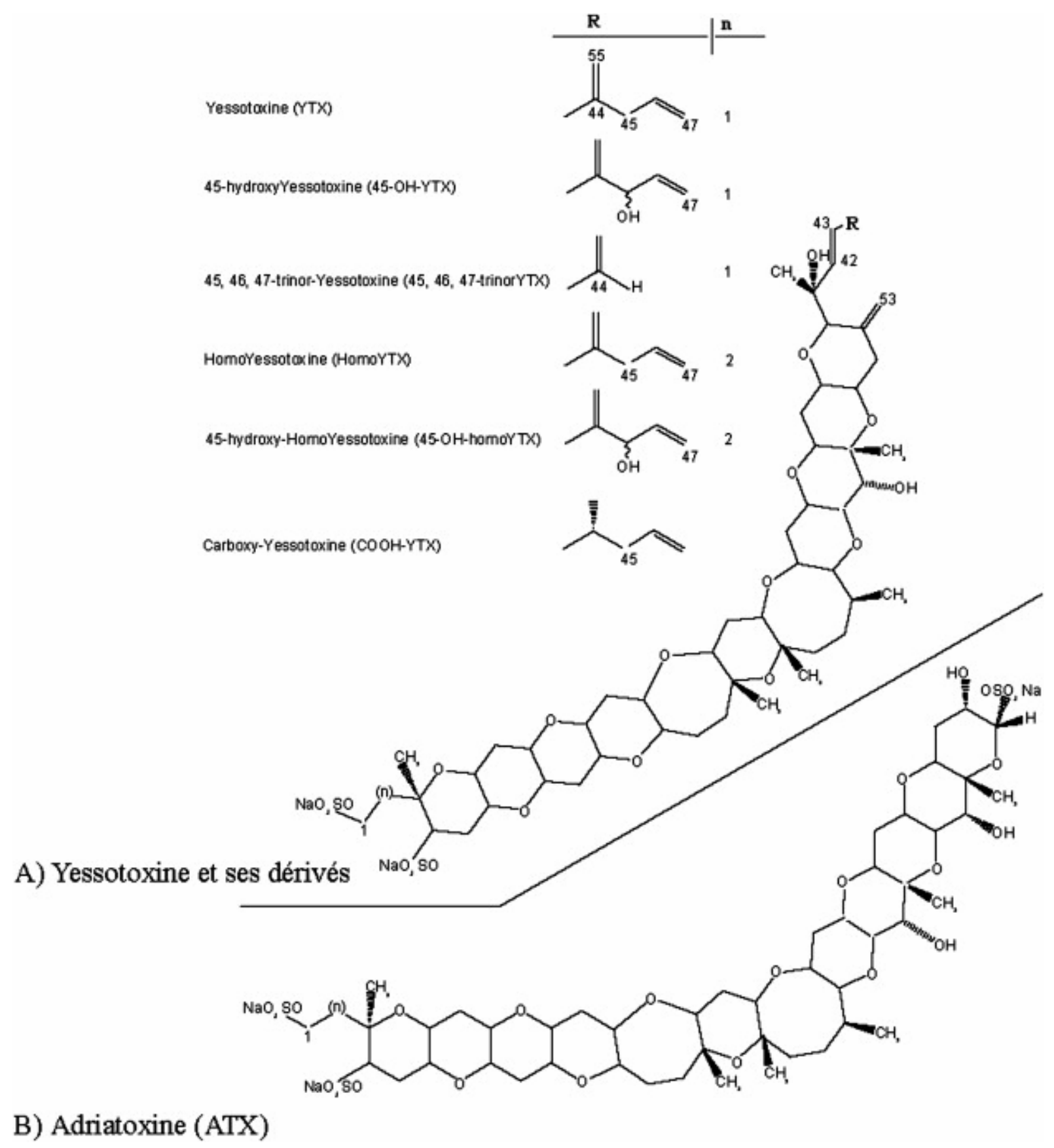

Fig. 1. Structures of various yessotoxins. 


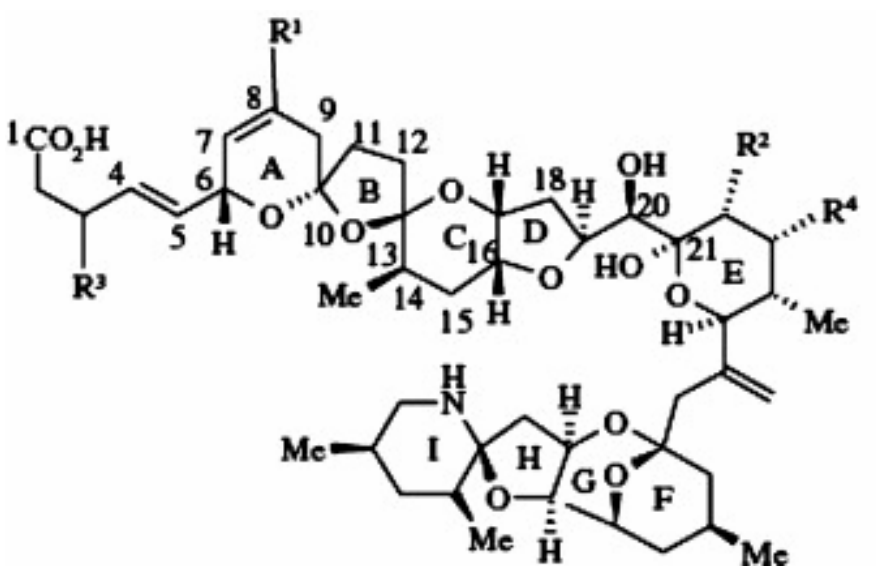

Name $\quad R^{1} R^{2} \quad R^{3} \quad R^{4}$

Aza-1: $\mathrm{H}$ Me $\mathrm{H}$ H Aza-2: Me Me $\mathrm{H}$ H Aza-3 : $\mathrm{H}$ H $\mathrm{H}$ H Aza-4: $\mathrm{H}$ H OH $\mathrm{H}$ Aza-5: $\mathrm{H} \quad \mathrm{H} \quad \mathrm{H}$ OH Aza-6: $\mathrm{Me} \mathrm{H}_{\mathrm{H}} \mathrm{H}$ Aza-7 : $\mathrm{H}$ Me $\mathrm{OH} \mathrm{H}$ Aza-8: $\mathrm{H}$ Me $\mathrm{H}$ OH Aza-9: $\mathrm{Me} \mathrm{H}$ OH $\mathrm{H}$ Aza-10: $\mathrm{Me} \mathrm{H} \mathrm{H}$ OH Aza-11: $\mathrm{Me} \mathrm{Me} \mathrm{OH} \mathrm{H}$

Fig. 2. Structures of azaspiracids.

HP or Whole tissues homogenate (2 g)

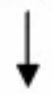

Acetone $(2 \times 3 \mathrm{ml})$ and methanol $(2 \mathrm{ml})$ extraction

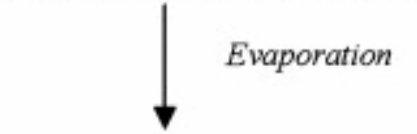

Residual aqueous phase

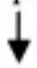

Add water up to $2 \mathrm{ml}$

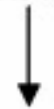

$\mathrm{CH}_{2} \mathrm{Cl}_{2}$ partitioning $(4,3$ and $2 \mathrm{ml})$

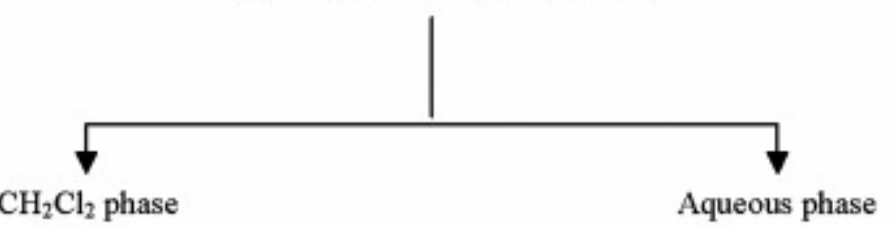

Containing lipophilic toxins

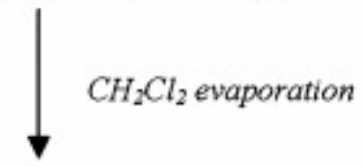

Dilution in $\mathrm{MeOH}(5 \mathrm{ml})$

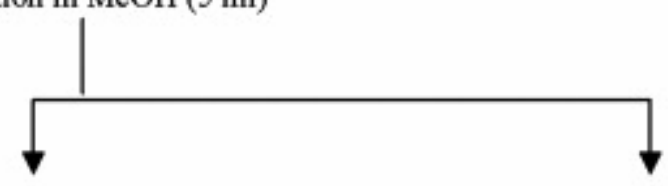

Aliquot filtrated on $0.2 \mu \mathrm{m}$

LC/MS analysis of OA, DTX-1,-2 (free forms)

PTXs, AZAs, YTXs, SPXs, GYMs
Hydrolysis of DTX-3 (1 ml)

$150 \mu \mathrm{lNaOH} 2.5 \mathrm{M}$,

$40 \min$ at $75^{\circ} \mathrm{C}$

$150 \mu \mathrm{l} \mathrm{HCl} 2.5 \mathrm{M}$

Aliquot filtrated on $0.2 \mu \mathrm{m}$

LC-MS/MS analysis of total OA, DTX-1,-2

(free and DTX-3 forms )

Fig. 3. Extraction procedure for lipophilic toxin analysis by LC-MS/MS. 


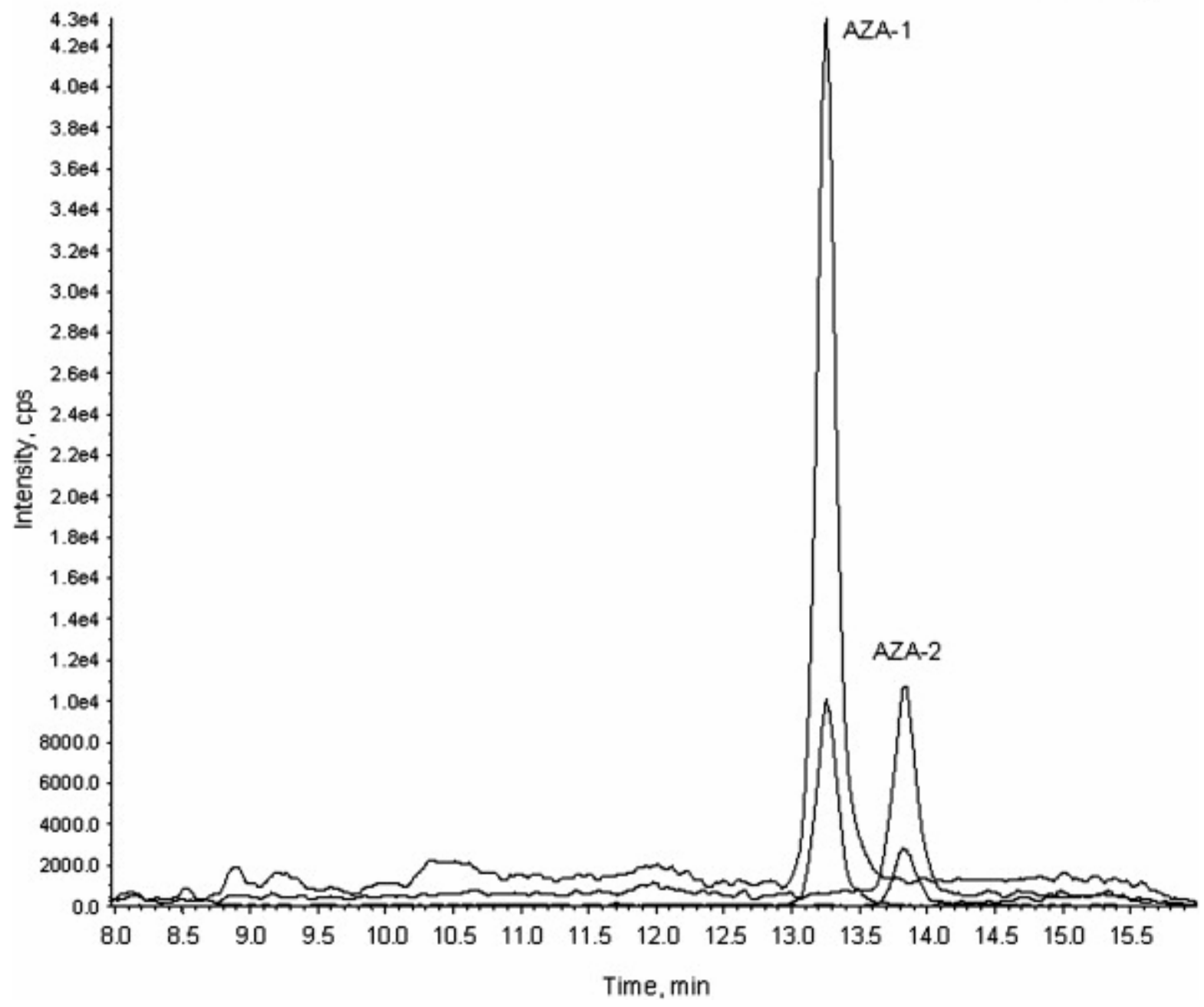

Fig. 4. Azaspiracids profile obtained by CL-SM/SM of whole Queen scallops (Aequipecten opercularis) tissue from Northern Brittany during summer 2006. 


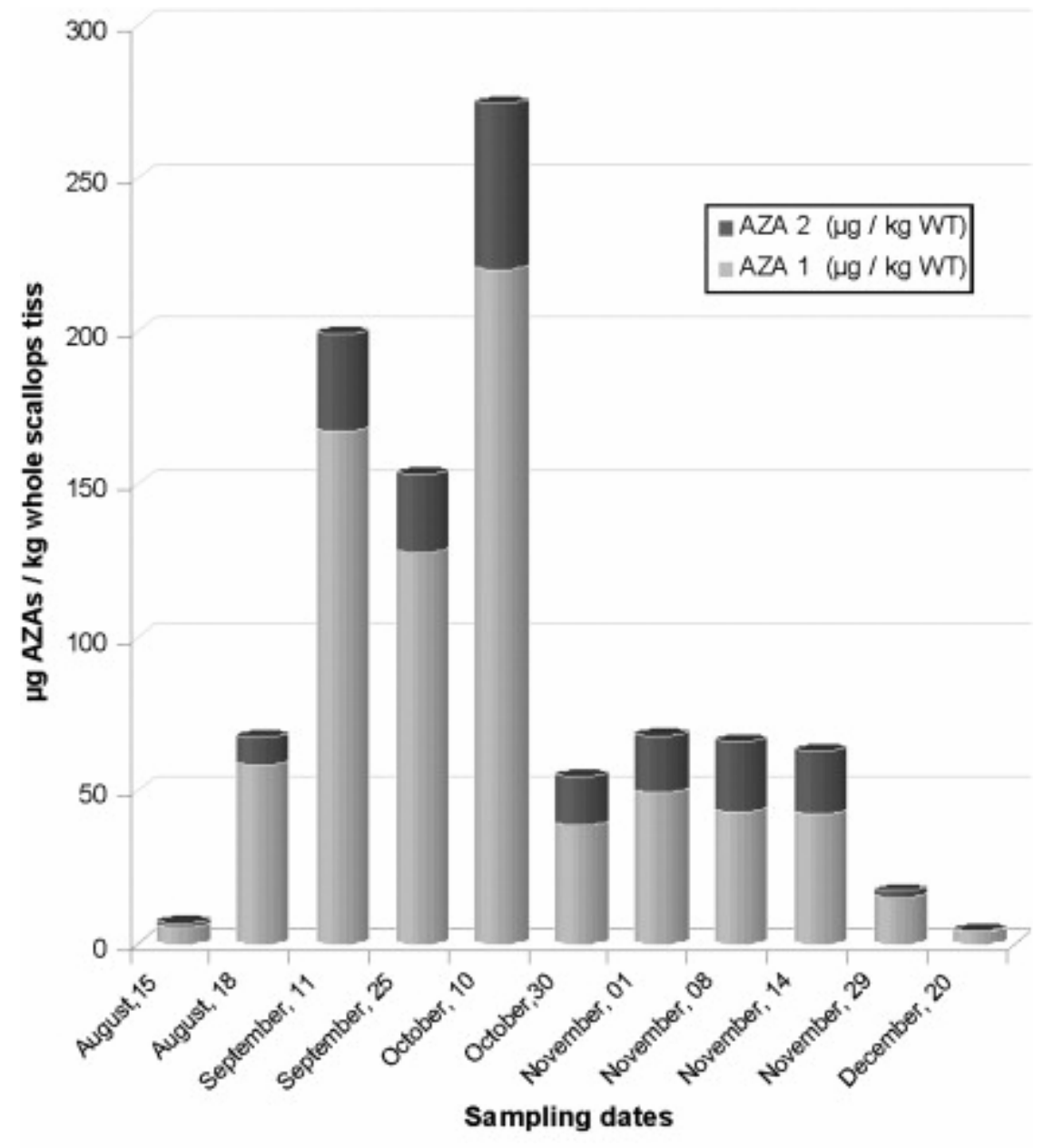

Fig. 5. Distribution of AZA-1 and AZA-2 in whole Queen scallops (Aequipecten opercularis) tissue from Northern Brittany during August-December 2006. 


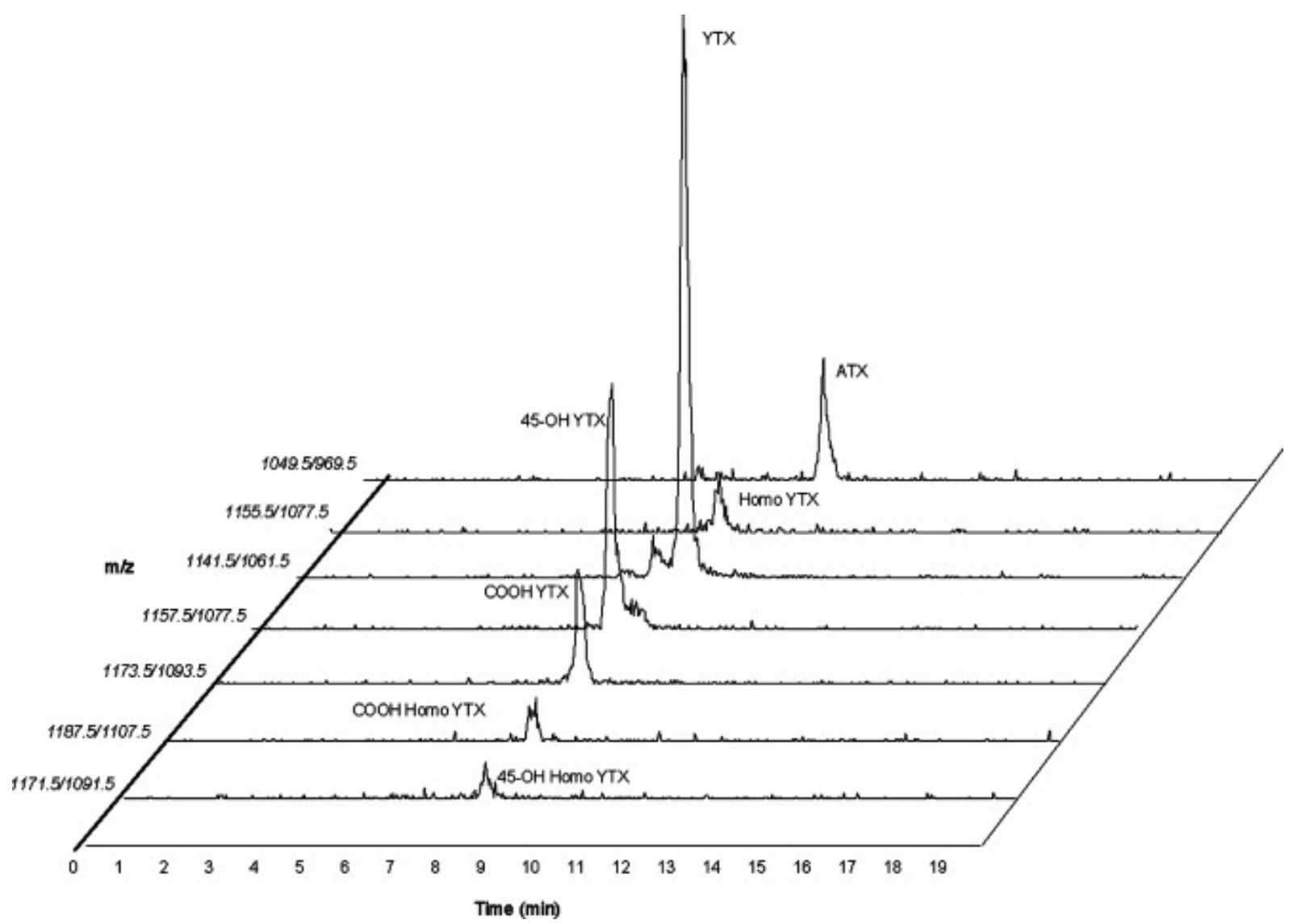

Fig. 6. Yessotoxins profiles of mussels hepatopancreas from Mediterranean coast in July 2007.

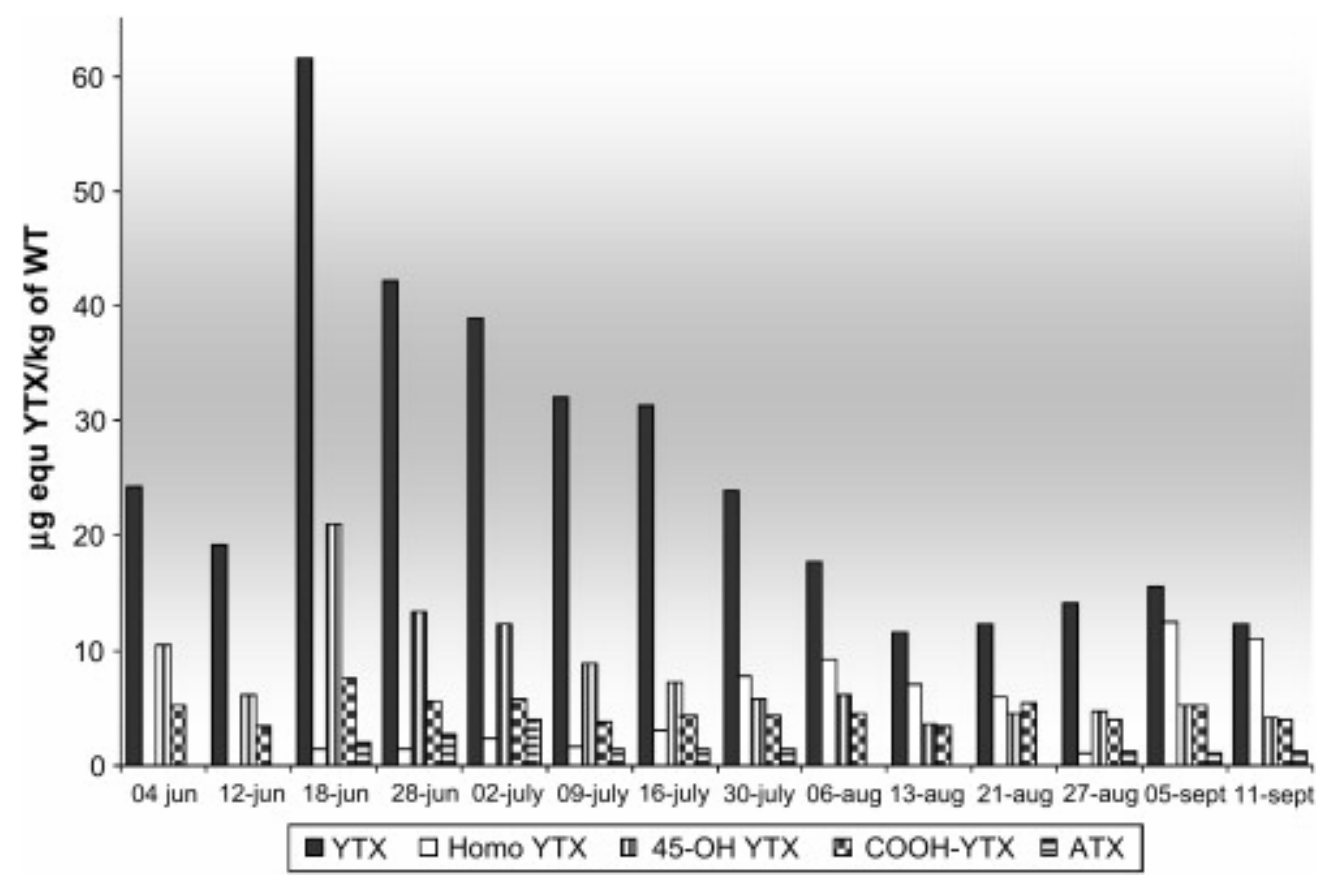

Fig. 7. Yessotoxins toxins profile in whole mussel tissue (WT) extract from Mediterranean coast (Ingril Lagoon) during summer 2007. 